\title{
PARTIAL LEAST SQUARES-STRUCTURAL EQUATION MODELING PADA HUBUNGAN ANTARA TINGKAT KEPUASAN MAHASISWA DAN KUALITAS GOOGLE CLASSROOM BERDASARKAN METODE WEBQUAL 4.0
}

\author{
Reny Rian Marliana*
}

\begin{abstract}
This paper studied a relationship between the quality of google classroom and student satisfaction. The quality of google classroom measured based on the Webqual 4.0 which is consists of four variables i.e. information quality, service interaction quality, user interface quality and usability. The relationship modeling between these latent variables and the student satisfaction was done by using the Partial Least Squares-Structural Equation Modeling (PLS-SEM). Estimation parameters of the model used PLS-SEM algorithm and Ordinary Least Square (OLS) method. Data was collected using a questionnaire to 89 students of google classroom's Probability and Statistics Course, Odd Semester 2017-2018 at STMIK Sumedang. The result showed the information quality, the service interaction quality and the user interface quality does not have significantly influence of the student satisfaction. Each of the total effects are 0.149; 0.011 and -0.155. While the usability has a significant effect to the student satisfaction positively with total effect 0.707.
\end{abstract}

Keywords : partial least squares, pls-sem, webqual 4.0

\begin{abstract}
Abstrak
Hubungan antara kualitas google classroom dan tingkat kepuasan mahasiswa dipelajari pada paper ini. Kualitas google classroom diukur berdasarkan metode Webqual 4.0 yang terdiri atas empat variabel laten yaitu kualitas informasi, kualitas interaksi layanan, kualitas antar muka pengguna dan kegunaa. Pemodelan hubungan antara keempat laten variabel tersebut dengan tingkat kepuasan mahasiswa dilakukan dengan menggunakan Partial Least Squares- Structural Equation Modeling (PLS-SEM). Estimasi parameter model dilakukan dengan menggunakan algoritma PLS-SEM yang didasarkan pada metode Ordinary Least Square (OLS). Data penelitian diperoleh melalui penyebaran 89 kuesioner terhadap mahasiswa yang terdaftar pada google classroom mata kuliah Probabilitas dan Statistika pada Semester Gasal 2017-2018 di STMIK Sumedang. Hasil analisis menunjukkan bahwa kualitas informasi, kualitas antar muka penggunan dan kualitas interaksi layanan tidak berpengaruh secara signifikan terhadap tingkat kepuasan mahasiswa dengan total pengaruh berturut-turut 0,$149 ; 0,011$ dan $-0,155$. Sementara variabel Usability berpengaruh secara signifikan terhadap tingkat kepuasan mahasiswa dengan total pengaruh sebesar 0,707 .
\end{abstract}

Keywords : partial least squares, pls-sem, webqual 4.0

${ }^{*}$ Teknik Informatika, STMIK Sumedang

Email: renyrianmarliana@gmail.com 


\section{PENDAHULUAN}

Google Classroom merupakan bagian dari Google for Education. Google Classroom merupakan sebuah serambi pembelajaran campuran yang diperuntukkan bagi setiap ruang lingkup Pendidikan, yang dimaksudkan untuk menemukan jalan keluar atas kesulitan dalam membuat, membagikan dan menggolong-golongkan setiap penugasan tanpa kertas [2]. Gooogle Classroom terhubung dengan semua layanan Google for Education lainnya seperti Google Mail, Google Drive, Google Calender, Google Docs, Google Sheets, Google Slides dan Google Sites dalam proses pembelajarannya. Dengan demikian Google classroom dapat membantu memudahkan pendidik dan siswa dalam melaksanakan kegiatan belajar mengajar dengan lebih menarik dan lebih efisien dalam hal pengelolaan waktu, terutama dalam hal pengumpulan tugas, distribusi tugas dan komunikasi pendidik dan siswa [9].

Sekolah Tinggi Manajemen Informatika dan Komputer (STMIK) Sumedang, telah memanfaatkan google classroom sebagai salah satu komunikasi pembelajaran melalui media online yang dapat diakses baik melalui web browser maupun melalui aplikasi pada smartphone. Tujuan penggunaan Google Classroom tersebut untuk meningkatkan pelayanan pembelajaran menjadi lebih baik. Sebagai bahan pertimbangan dan evaluasi, perlu diketahui factor-faktor yang mempengaruhi tingkat kepuasan mahasiswa dalam menggunakan google classroom. Pengukuran tingkat kepuasaan tersebut dapat didasarkan pada kualitas dari google classroom itu sendiri. Sehingga akan diperoleh sebuah model hubungan antara kualitas google classroom dengan tingkat kepuasan mahasiswa.

WebQual 4.0 merupakan salah satu metode yang dapat digunakan dalam mengukur kualitas sebuah website. WebQual merupakan sebuah teknik pengukuran kualitas website yang didasarkan pada persepsi penggunanya $[1,10]$. Penerapan metode WebQual 4.0 untuk mengukur kualitas website dapat membantu untuk mengetahui faktor-faktor yang berpengaruh terhadap kepuasan pengguna akhir [12]. Selain dapat digunakan untuk mengukur kualitas sebuah website, metode WebQual 4.0 dapat pula digunakan untuk mengukur kualitas sebuah aplikasi [4]. Dengan demikian, metode WebQual 4.0 dapat digunakan dalam mengukur kualitas Google Classroom yang dapat diakses baik melalui web browser pada Personal Computer maupun aplikasi pada smartphone.

Metode WebQual 4.0 terdiri atas tiga dimensi yaitu Usability, kualitas informasi dan kualitas layanan $[3,4,8,10,11,12]$. Oleh karena, pengguna sebuah website ataupun aplikasi akan melihat tampilan dari website atau aplikasi itu sendiri sebagai interaksi pertama, terdapat sebuah modifikasi pada metode WebQual 4.0 melalui penambahan dimensi mengenai kualitas antar muka pengguna (user interface quality) [1]. Pengukuran kualitas google classroom pada penelitian ini dilakukan berdasarkan 4 dimensi yang terdiri atas kualitas informasi, kualitas layanan interaksi, kualitas antar muka pengguna dan Usability.

Untuk mengetahui faktor-faktor yang mempengaruhi tingkat kepuasan mahasiswa dalam menggunakan google classroom, maka diperlukan sebuah model yang dapat menggambarkan hubungan antara kualitas google classroom dengan tingkat kepuasan mahasiswa berdasarkan Metode WebQual 4.0. Model tersebut dapat menggambarkan pengaruh kualitas informasi, kualitas layanan interaksi, kualitas antar muka pengguna dan kegunanan terhadap tingkat kepuasan mahasiswa dalam menggunakan google classroom. Pada beberapa penelitian, pemodelan dilakukan dengan menggunakan analisis regresi linear $[3,4,8,10,11,12]$. Sementara dimensi-dimensi pada metode WebQual 4.0 merupakan sebuah variabel laten yang tidak dapat diukur secara langsung. Melainkan dimanifestasikan ke dalam beberapa indikator dan diukur dalam bentuk item pertanyaan dengan berbagai skala pengukuran.

Hasil penerapan analisis regresi pada beberapa penelitian $[3,4,8,10,11,12]$ tidak dapat menginterpretasikan hubungan antara masing-masing dimensi pada Webqual 4.0 terhadap tingkat kepuasan user. Kesulitan interpretasi ini dapat disebabkan oleh adanya penjumlahan semua dimensi pada Webqual 4.0 menjadi satu variabel kualitas website [10]. Selain itu, 
dapat juga disebabkan oleh analisis regresi yang hanya bisa menghitung nilai koefisien determinasi yang mewakili semua dimensi pada Webqual 4.0 dalam persamaan taksiran regresi yang diperoleh $[3,4,8,11,12]$.

Oleh karena itu, diperlukan sebuah pemodelan yang dapat digunakan dalam pemodelan variabel laten kualitas informasi, kualitas layanan interaksi, kualitas antar muka pengguna dengan variabel laten tingkat kepuasan mahasiswa dalam menggunakan google classroom dibandingkan dengan menggunakan analisis regresi linear. Salah satu model yang dapat digunakan adalah Structural Equation Modeling (SEM). SEM merupakan sebuah metode analisis data multivariat yang digunakan untuk menguji hipotesis pada hubungan-hubungan antara variabel-variabel terobservasi dan laten. Terdapat dua pendekatan yang digunakan pada SEM yaitu Covariance-based SEM (CB-SEM) dan Partial Least Squares SEM (PLS-SEM) $[5,6,7,13]$.

CB-SEM adalah pendekatan SEM yang digunakan ketika ukuran sampel besar dan data berdistribusi normal, sedangkan PLS-SEM dapat digunakan ketika ukuran sampel kecil dan data tidak berdistribusi normal $[5,6,7,13]$. Dikarenakan ukuran populasi pada penelitian ini kecil sehingga ukuran sampel pun kecil, maka metode SEM yang dapat diterapkan adalah PLS-SEM. Dengan demikian, pemodelan variabel laten kualitas informasi, kualitas layanan interaksi, kualitas antar muka pengguna dengan variabel laten tingkat kepuasan mahasiswa dalam menggunakan google classroom pada penelitian ini dilakukan melalui metode PLSSEM.

\section{PARTIAL LEAST-SQUARES STRUCTURAL EQUATION MODELING (PLS-SEM)}

Stuctural Equation Modeling (SEM) merupakan teknik analisis data multivariat generasi kedua yang dapat membantu peneliti dalam menguji hubungan antara variabel laten. Terdapat dua pendekatan pada estimasi hubungan antar variabel pada SEM yaitu $C B$-SEM dan PLS-SEM [6,7,13]. Covariance Based-Structural Equation Modeling (CB-SEM) adalah pendekatan pada SEM yang digunakan ketika tujuan dari penelitian adalah menguji sebuah teori, mengkonfirmasi sebuah teori dan membandingkan beberapa alternatif teori, ukuran sampel besar dan data berdisitribusi normal [6,7,13]. Sedangkan Partial-Least SquaresStructural Equation Modeling (PLS-SEM) merupakan metode nonparametrik yang tidak memerlukan asumsi distribusi dari data. PLS-SEM dapat digunakan pada data yang tidak berdistribusi normal karena algoritma PLS mentransformasikan data yang tidak normal melalui teorema limit pusat [7]. Dengan kata lain PLS-SEM dapat digunakan pada data dengan ukuran sampel yang kecil. Secara umum, PLS-SEM memiliki tingkat statistical power dan menunjukkan konvergensi yang lebih tinggi dibandingkan dengan CB-SEM [7]. Ukuran sampel minimal untuk PLS-SEM harus sama atau lebih besar dari :

a. Sepuluh (10) kalinya jumlah terbanyak dari indikator formatif yang digunakan untuk mengukur sebuah konstruk.

b. Sepuluh (10) kalinya jumlah jalur inner model terbanyak yang terhubung langsung pada konstruk tertentu di inner model.

Tahapan analisis pada PLS-SEM tidak jauh berbeda dengan CB-SEM. Perbedaanya hanya terletak pada metode penaksiran parameter dan tidak adanya pengujian goodness of fit (GOF) pada PLS-SEM. Tahapan analisis PLS-SEM pada penelitian ini terdiri atas model spesifikasi, estimasi parameter model, pengujian model struktural dan pengujian model pengukuran.

\subsection{Model Spesifikasi}

Model spesifikasi pada PLS-SEM dilakukan dengan membuat sebuah path diagram (Gambar 1) yang menggambarkan hubungan antara variabel eksogen dan endogen (model struktural/inner model) dan hubungan antara variabel eksogen dan endogen terhadap indikatornya masing-masing (model pengukuran/outer model). Pada penelitian ini, model 


\section{Reny Rian Marliana}

struktural dan model pengukuran antar variabel penelitian (Tabel 1) dibentuk berdasarkan modifikasi pada metode WebQual 4.0 [1].

Tabel 1. Variabel Penelitian

\begin{tabular}{|c|c|c|c|c|}
\hline Variabel & & Item Pertanyaan & Skala Ukur & Notasi \\
\hline \multirow{6}{*}{$\begin{array}{l}\text { Kualitas } \\
\text { Informasi } \\
\left(\mathbf{Y}_{1}\right)\end{array}$} & 1 & $\begin{array}{l}\text { Google Classroom menyediakan } \\
\text { informasi yang akurat }\end{array}$ & Rating Scale $1 \mathrm{~s} / \mathrm{d} 5$ & KI1 \\
\hline & 2 & $\begin{array}{l}\text { Google Classroom menyediakan } \\
\text { informasi yang terpercaya }\end{array}$ & Rating Scale 1 s/d 5 & $\mathrm{KI} 2$ \\
\hline & 3 & $\begin{array}{l}\text { Google Classroom menyediakan } \\
\text { informasi tepat waktu }\end{array}$ & Rating Scale 1 s/d 5 & $\mathrm{KI} 3$ \\
\hline & 4 & $\begin{array}{l}\text { Google Classroom menyediakan } \\
\text { informasi yang relevan }\end{array}$ & Rating Scale 1 s/d 5 & KI4 \\
\hline & 5 & $\begin{array}{l}\text { Google Classroom menyediakan } \\
\text { informasi yang mudah dimengerti }\end{array}$ & Rating Scale 1 s/d 5 & KI5 \\
\hline & 6 & $\begin{array}{l}\text { Google Classroom menyediakan } \\
\text { informasi yang detail }\end{array}$ & Rating Scale $1 \mathrm{~s} / \mathrm{d} 5$ & KI6 \\
\hline \multirow{4}{*}{$\begin{array}{l}\text { Kualitas } \\
\text { Interaksi } \\
\text { Layanan } \\
\left(\mathrm{Y}_{2}\right)\end{array}$} & 7 & $\begin{array}{l}\text { Mahasiswa merasa aman terhadap } \\
\text { informasi pribadi }\end{array}$ & Rating Scale $1 \mathrm{~s} / \mathrm{d} 5$ & KIL7 \\
\hline & 8 & $\begin{array}{l}\text { Google Classroom memberikan } \\
\text { ruang untuk personalisasi }\end{array}$ & Rating Scale 1 s/d 5 & KIL8 \\
\hline & 9 & $\begin{array}{l}\text { Google Classroom memberikan } \\
\text { ruang untuk anggota kelas }\end{array}$ & Rating Scale 1 s/d 5 & KIL9 \\
\hline & 10 & $\begin{array}{l}\text { Google Classroom memberikan } \\
\text { kemudahan untuk berkomunikasi } \\
\text { dengan dosen }\end{array}$ & Rating Scale $1 \mathrm{~s} / \mathrm{d} 5$ & KIL10 \\
\hline \multirow{7}{*}{$\begin{array}{l}\text { Kualitas } \\
\text { Antar } \\
\text { Muka } \\
\text { Pengguna } \\
\left(\mathbf{Y}_{3}\right)\end{array}$} & 11 & $\begin{array}{l}\text { Google Classroom memberikan } \\
\text { gambar yang tepat }\end{array}$ & Rating Scale 1 s/d 5 & KAMP11 \\
\hline & 12 & $\begin{array}{l}\text { Google Classroom menggunakan } \\
\text { huruf (font) yang sesuai }\end{array}$ & Rating Scale 1 s/d 5 & KAMP12 \\
\hline & 13 & $\begin{array}{l}\text { Google Classroom menggunakan } \\
\text { warna yang sesuai }\end{array}$ & Rating Scale 1 s/d 5 & KAMP13 \\
\hline & 14 & $\begin{array}{l}\text { Google Classroom menggunakan } \\
\text { desain halaman yang sesuai }\end{array}$ & Rating Scale 1 s/d 5 & KAMP14 \\
\hline & 15 & $\begin{array}{l}\text { Link pada Google Classroom } \\
\text { bekerja dengan baik }\end{array}$ & Rating Scale 1 s/d 5 & KAMP15 \\
\hline & 16 & $\begin{array}{l}\text { Kecepatan download pada } \\
\text { halaman Google Classroom baik }\end{array}$ & Rating Scale $1 \mathrm{~s} / \mathrm{d} 5$ & KAMP16 \\
\hline & 17 & $\begin{array}{l}\text { Google Classroom memiliki tata } \\
\text { letak yang terstruktur dan } \\
\text { konsisten }\end{array}$ & Rating Scale 1 s/d 5 & KAMP17 \\
\hline \multirow[t]{3}{*}{$\begin{array}{l}\text { Usability } \\
\left(\mathbf{Y}_{4}\right)\end{array}$} & 18 & $\begin{array}{l}\text { Mahasiswa dengan mudah dapat } \\
\text { belajar menggunakan Google } \\
\text { Classroom }\end{array}$ & Rating Scale 1 s/d 5 & $\mathrm{U} 18$ \\
\hline & 19 & $\begin{array}{l}\text { Interaksi mahasiswa dengan } \\
\text { Google Classroom jelas dan dapat } \\
\text { dimengerti }\end{array}$ & Rating Scale $1 \mathrm{~s} / \mathrm{d} 5$ & U19 \\
\hline & 20 & $\begin{array}{l}\text { Google Classroom mudah untuk } \\
\text { dinavigasi }\end{array}$ & Rating Scale $1 \mathrm{~s} / \mathrm{d} 5$ & $\mathrm{U} 20$ \\
\hline
\end{tabular}




\section{Reny Rian Marliana}

\begin{tabular}{lclcc}
\hline \multicolumn{1}{c}{ Variabel } & & \multicolumn{1}{c}{ Item Pertanyaan } & Skala Ukur & Notasi \\
\hline & 21 & $\begin{array}{l}\text { Google Classroom mudah untuk } \\
\text { digunakan }\end{array}$ & Rating Scale 1 s/d 5 & U21 \\
& 23 & $\begin{array}{l}\text { Google Classroom mengandung } \\
\text { nilai kompetensi } \\
\text { Google Classroom menciptakan } \\
\text { pengalaman positif bagi } \\
\text { mahasiswa }\end{array}$ & Rating Scale 1 s/d 5 & U22 \\
& 24 & $\begin{array}{l}\text { Google Classroom memiliki } \\
\text { tampilan yang menarik }\end{array}$ & Rating Scale 1 s/d 5 & U24 \\
\hline $\begin{array}{l}\text { Tingkat } \\
\text { Kepuasan } \\
\text { (Y) }\end{array}$ & 25 & $\begin{array}{l}\text { Secara keseluruhan Google } \\
\text { Classroom memuaskan }\end{array}$ & Rating Scale 1 s/d 5 & TK25 \\
\hline
\end{tabular}

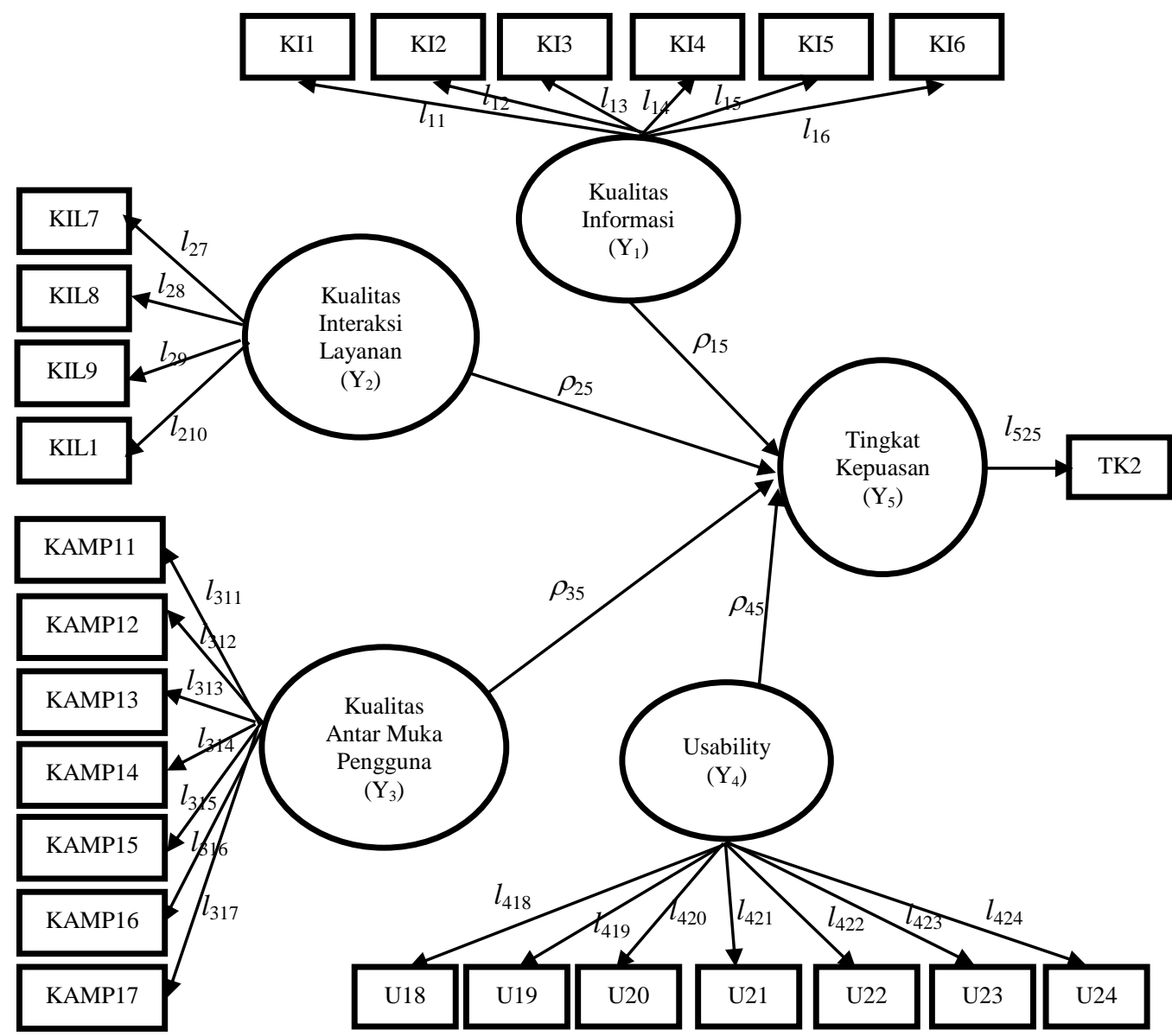

Gambar 1. Model Spesifikasi

\subsection{Estimasi Parameter Model}

Penaksiran atau estimasi parameter model pada Gambar 1 dilakukan dengan menggunakan algoritma PLS-SEM yang didasarkan pada metode Ordinary Least 
Square (OLS) [6]. Algoritma PLS-SEM dikerjakan menggunakan model regresi parsial yang dilakukan secara iterasi dalam dua tahap. Tahap pertama adalah penaksiran skor konstruk. Tahap kedua adalah penaksiran nilai outer loadings $(l)$, path coefficients $(\rho)$ dan nilai $R^{2}$ dari variabel laten endogen. Nilai outer loadings $(l)$, diestimasi melalui regresi sederhana pada setiap indikator terhadap masing-masing konstruksnya. Sedangkan path coefficients $(\rho)$ dan nilai $R^{2}$ diestimasi melalui analisis regresi antar variabel endogen. Algoritma PLS-SEM dihentikan ketika konvergensi sudah tercapai atau nilai maksimal angka iterasi tercapai.

\subsection{Evaluasi Model Pengukuran (Outer Model)}

Evaluasi model pengukuran pada PLS-SEM membangun sebuah kriteria evaluasi non-parametrik dan menggunakan prosedur bootstapping dan blindfolding [6]. Fokus dari evaluasi model pengukuran adalah mengevaluasi validitas dan reliabilitas dari pengukuran konstruk atau indikator. Pada model pengukuran reflektif di penelitian ini, evaluasi model pengukuran dilakukan dengan menggunakan internal consistency (composite reliability), indikator reliability, convergent validity (average variance extracted) dan discriminat validity.

Pengukuran internal consistency dilakukan dengan menggunakan statistic composite reliability $\left(\rho_{c}\right)$ yang dihitung melalui :

$$
\rho_{c}=\frac{\left(\sum_{i} l_{i}\right)^{2}}{\left(\sum_{i} l_{i}\right)^{2}+\sum_{i} \operatorname{var}\left(e_{i}\right)}
$$

dengan $l_{i}$ adalah standardized outer loading variabel indikator ke- $i$ pada konstruk tertentu, $e_{i}$ adalah eror pengukuran variabel indikator ke- $i$ dan $\operatorname{var}\left(e_{i}\right)$ adalah varians dari eror pengukuran variabel indikator ke-i. nilai composite reliability berada dalam rentang 0 sampai dengan 1 , semakin tinggi nilai menunjukkan semakin tinggi tingkat reliabilitas. Untuk dapat mengatakan sebuah variabel indikator memiliki nilai internal consistency yang cukup, nilai composite reliability harus lebih besar dari 0,708 [6].

Semakin tinggi nilai outer loading pada sebuah konstruk menunjukkan bahwa indikator-indikator pada konstruk tersebut memiliki banyak kesamaan. Karakteristik ini disebut sebagai indikator reliability. Nilai outer loading pada semua indikator harus signifikan secara statistic dengan ketentuan nilai minimal adalah 0,708. Ketika nilai outer loading yang diperoleh berada dalam interval 0,4-0,7 harus dipertimbangkan untuk dikeluarkan dari model. Dengan catatan, jika penghapusan atau pengeluaran indikator tersebut dari model dapat meningkatkan nilai composite reliability dan nilai average variance extracted (AVE).

Secara umum, Convergent validity dapat diukur menggunakan nilai AVE dengan ketentuan nilai AVE harus lebih besar dari 0,5. Artinya, ketika nilai AVE lebih besar dari 0,5 maka secara rata-rata konstruk menjelaskan lebih dari setengahnya (50\%) varians setiap indikatornya. Sebaliknya jika nilai AVE lebih kecil dari 0,5 maka secara rata-rata terdapat lebih banyak kekeliruan dibandingkan dengan varians yang dijelaskan oleh konstruk.

Pengukuran discriminat validity dapat dilakukan salah satunya dengan menggunakan nilai cross loadings variabel indikator. Secara umum, nilai outer loadings dari sebuah variabel indikator harus lebih besar dari semua nilai outer loadings variabel indikator tersebut terhadap konstruk yang lain. 


\subsection{Evaluasi Model Struktural (Inner Model)}

Evaluasi model struktural (inner model) dilakukan dalam beberapa tahap yaitu pengujian kolinieritas, pengujian signifikansi hubungan pada model struktural dan mengukur nilai $R^{2}$. Pengujian kolinieritas dilakukan dengan menggunakan statistik VIF yang harus lebih besar dari 0,2 tetapi lebih kecil dari 5. Jika nilai yang diperoleh lebih kecil dari 0,2 dan atau lebih besar dari 5, konstruk harus dapat dipertimbangkan untuk dieliminasi atau dihilangkan dari model struktural atau digabungkan dalam satu konstruk yang lain.

Pengujian signifikansi hubungan pada model struktural dilakukan dengan menggunakan statistik $t$ yang diperoleh setelah path coefficient diestimasi. Algoritma PLS-SEM menghasilkan nilai path coefficient $(\rho)$ yang distandardisari dengan rentang nilai -1 sampai dengan +1 . Nilai path coefficient yang mendekati nilai +1 menunjukkan hubungan positif yang kuat sedangkan jika nilai nya mendekati -1 menunjukkan hubungan negatif yang kuat [7]. Statistik $t$ untuk path coefficient $\left(\rho_{i j}\right)$ antara variabel laten endogen $k e-i$ dan $k e-j$ dengan standard $s e_{i j}^{*}$ diperoleh melalui metode boostrap dengan formula:

$$
t=\frac{\rho_{i j}}{s e_{i j}^{*}}
$$

Nilai kritis yang digunakan ketika ukuran sampel lebih besar dari 30 dan pengujian dua pihak adalah 1,65 untuk taraf signifikansi 10\%, 1,96 untuk taraf signifikansi 5\% dan 2,57 untuk taraf signifikansi $1 \%$. Ketika nilai $t$ yang diperoleh lebih besar dari nilai kritis maka path coefficient signifikan pada taraf signifikansi yang digunakan.

Nilai koefisien determinasi $R^{2}$ merupakan ukuran akurasi model prediksi yang dihitung sebagai nilai korelasi yang dikuadratkan antara nilai actual dengan nilai prediksi konstruk variabel endogen tertentu. Dengan kata lain, koefisien ini menunjukkan pengaruh gabungan antara variabel laten eksogen pada variabel laten endogen. Nilai $R^{2}$ berada dalam rentang $O$ sampai dengan 1, dimana semakin tinggi nilai semakin tinggi nilai akurasi prediksi model yang diperoleh dengan kriteria 0,75 tinggi, 0,5 sedang dan 0,25 rendah [6].

\section{HASIL DAN PEMBAHASAN}

Data pada penelitian ini merupakan data primer yang dikumpulkan melalui penyebaran kuesioner terhadap 89 orang mahasiswa pengguna Google Classroom mata kuliah Probabilitas dan Statistika yang diampu oleh peneliti pada Semester Gasal 2017-2018.

\subsection{Model Prediksi dan Estimasi Parameter Model}

Hasil penaksiran parameter model pada Gambar 1 yang dilakukan melalui algoritma PLS-SEM adalah sebagai berikut : 


\section{Reny Rian Marliana}

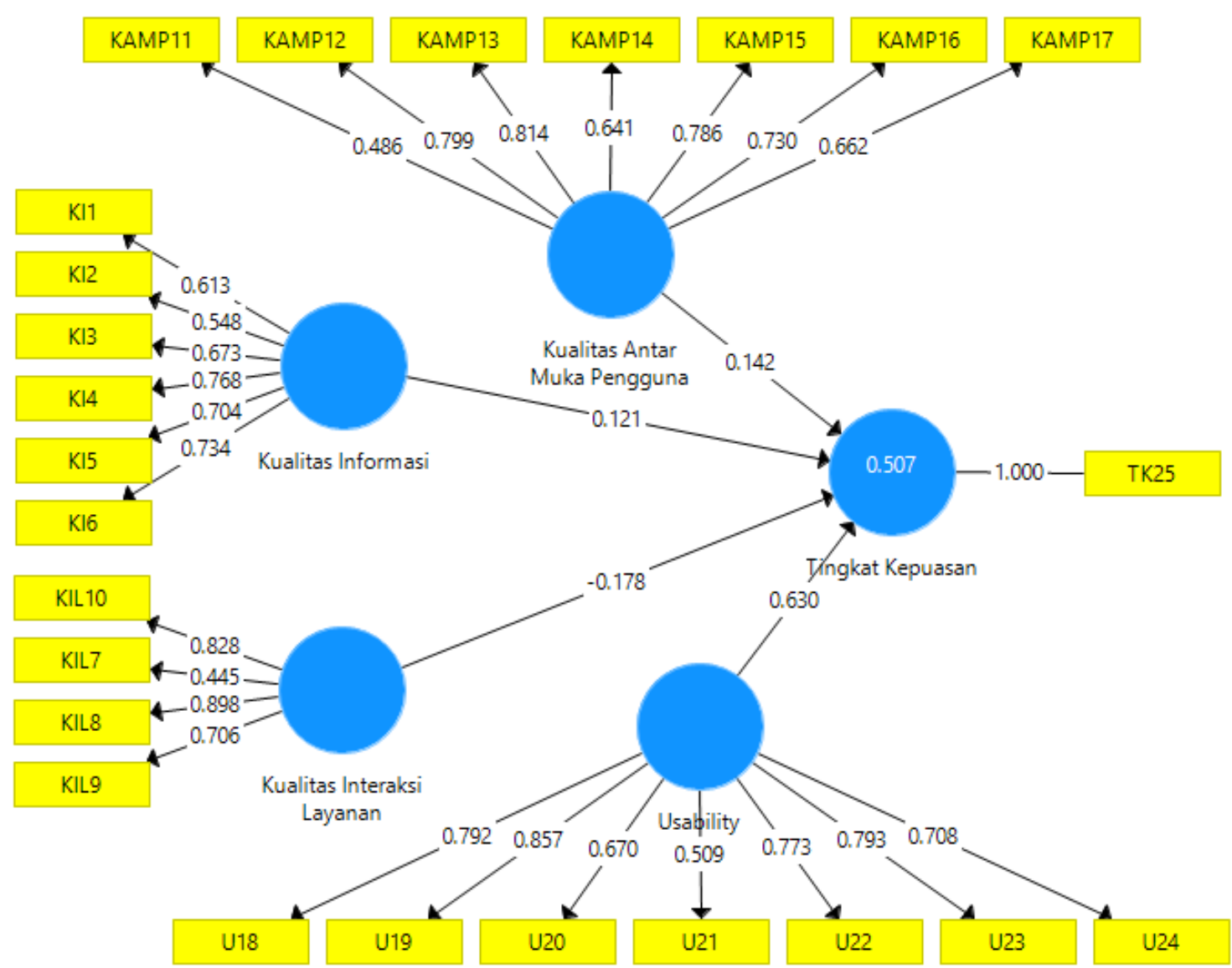

Gambar 2. Estimasi Parameter Model

\subsection{Evaluasi Model Pengukuran Reflective}

Evaluasi model pengukuran dilakukan dengan memeriksa (a) internal consistency reliability menggunakan statistic composite reliability, (b) indikator reliability menggunakan the indikator's outer loadings, (c) Convergent validity menggunakan statistic AVE dan (d) discriminant validity menggunakan Cross loadings.

Tabel 2. Construct Reliability and Validity

\begin{tabular}{lcccc}
\hline & $\begin{array}{l}\text { Cronbach's } \\
\text { Alpha }\end{array}$ & rho_A & $\begin{array}{l}\text { Composite } \\
\text { Reliability }\end{array}$ & $\begin{array}{l}\text { Average } \\
\text { Variance } \\
\text { Extracted } \\
\text { (AVE) }\end{array}$ \\
\hline $\begin{array}{l}\text { Kualitas Antar Muka } \\
\text { Pengguna }\end{array}$ & 0,833 & 0,863 & 0,875 & 0,505 \\
Kualitas Informasi & 0,761 & 0,772 & 0,834 & 0,459 \\
Kualitas Interaksi Layanan & 0,701 & 0,795 & 0,820 & 0,547 \\
Tingkat Kepuasan & 1,000 & 1,000 & 1,000 & 1,000 \\
Usability & 0,857 & 0,880 & 0,891 & 0,543 \\
\hline
\end{tabular}

Nilai composite reliability (Tabel 2) untuk semua konstruk lebih besar dari 0,798 sehingga dapat dikatakan bahwa konstruk memiliki konsistensi internal yang cukup tinggi. 


\section{Reny Rian Marliana}

Tabel 3. Outer Loadings

\begin{tabular}{lccccc}
\hline & $\begin{array}{l}\text { Kualitas Antar } \\
\text { Muka } \\
\text { Pengguna }\end{array}$ & $\begin{array}{l}\text { Kualitas } \\
\text { Informasi }\end{array}$ & $\begin{array}{l}\text { Kualitas } \\
\text { Interaksi } \\
\text { Layanan }\end{array}$ & $\begin{array}{l}\text { Tingkat } \\
\text { Kepuasan }\end{array}$ & Usability \\
\hline KAMP11 & 0,486 & & & & \\
KAMP12 & 0,799 & & & \\
KAMP13 & 0,814 & & & & \\
KAMP14 & 0,641 & & & & \\
KAMP15 & 0,786 & & & & \\
KAMP16 & 0,730 & & & \\
KAMP17 & 0,663 & & & \\
KI1 & & 0,613 & & \\
KI2 & & 0,548 & & \\
KI3 & & 0,673 & & \\
KI4 & & 0,768 & & \\
KI5 & & 0,704 & & \\
KI6 & & 0,734 & & \\
KIL10 & & & 0,828 & \\
KIL7 & & & 0,445 & \\
KIL8 & & & 0,898 & \\
KIL9 & & & 0,706 & \\
TK25 & & & & \\
U18 & & & & \\
U19 & & & & \\
U20 & & & & \\
U21 & & & & \\
U22 & & & & \\
U23 & & & & \\
U24 & & & & \\
\hline
\end{tabular}

Sementara, nilai outer loadings (Tabel 3) untuk beberapa indikator masih berada dalam interval $0,40-0,70$ sehingga perlu dipertimbangkan untuk memeriksa kembali indikatorindikator yang memiliki nilai outer loading dalam rentang tersebut. Jika model baru yang dihasikan dapat meningkatkan nilai composite reliability dan AVE maka indikator tersebut perlu dikeluarkan dari model utama.

Perbandingan nilai composite reliability dan AVE pada model utama dan model penyesuaian ditunjukkan pada Tabel 4 dan Tabel 5. Model penyesuaian (Gambar 3) adalah model yang terbentuk dengan menghapus beberapa indikator sesuai dengan Tabel 3. Hasil perbandingan menunjukkan bahwa model penyesuaian (Gambar 3) mampu meningkatkan nilai composite reliability dan AVE. Dengan demikian, model penyesuaian yang akan digunakan untuk analisis lanjut pada penelitian ini. 


\section{Reny Rian Marliana}

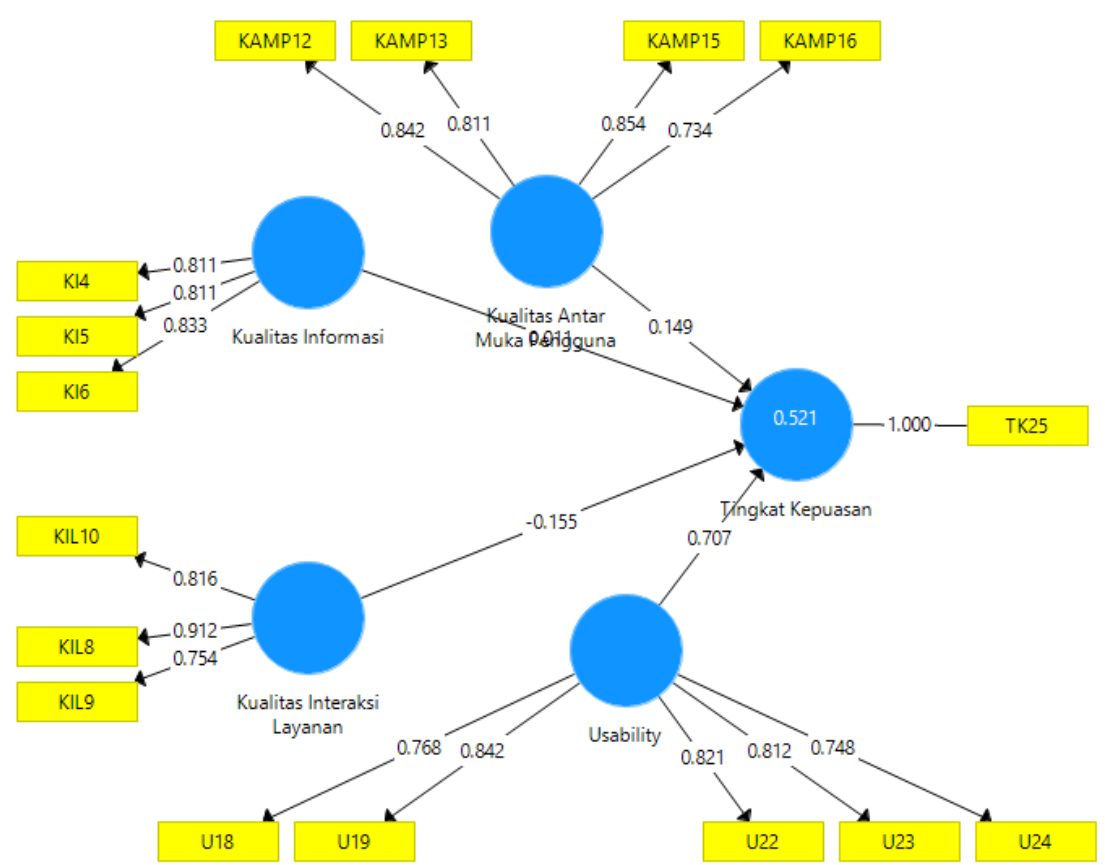

Gambar 3. Model Penyesuaian

Tabel 4. Perbandingan nilai Composite Reliability

\begin{tabular}{lcc}
\hline Composite Reliability & Model Utama & Model Baru \\
\hline Kualitas Antar Muka Pengguna & 0,875 & 0,885 \\
Kualitas Informasi & 0,834 & 0,859 \\
Kualitas Interaksi Layanan & 0,820 & 0,868 \\
Tingkat Kepuasan & 1,000 & 1,000 \\
Usability & 0,891 & 0,898 \\
\hline
\end{tabular}

Tabel 5. Perbandingan nilai Average Variance Extracted (AVE)

\begin{tabular}{lcc}
\hline AVE & Model Utama & Model Baru \\
\hline Kualitas Antar Muka Pengguna & 0,505 & 0,658 \\
Kualitas Informasi & 0,459 & 0,670 \\
Kualitas Interaksi Layanan & 0,547 & 0,689 \\
Tingkat Kepuasan & 1,000 & 1,000 \\
Usability & 0,543 & 0,638 \\
\hline
\end{tabular}

\subsection{Evaluasi Model Struktural}

Sebelum dilakukan pengujian signifikansi model struktural, terlebih dahulu dilakukan pengujian kolinieritas antara variabel kualitas antar muka, kualitas informasi, kualitas interaksi layanan dan usability terhadap tingkat kepuasan melalui statistik VIF. Semua nilai VIF lebih besar dari 0,2 dan lebih kecil dari 5 (Tabel 6). 
Reny Rian Marliana

Tabel 6. Pengujian Kolinieritas

\begin{tabular}{lc}
\hline \multicolumn{1}{c}{ Variabel Laten Eksogen } & VIF \\
\hline Kualitas Antar Muka Pengguna & 1,883 \\
Kualitas Informasi & 1,842 \\
Kualitas Interaksi Layanan & 1,990 \\
Usability & 2,568 \\
\hline
\end{tabular}

Signifikansi hubungan pada model Struktural (Tabel 7) menunjukkan bahwa tidak terdapat hubungan yang signifikan antara kualitas antar muka pengguna, kualitas informasi dan kualitas interaksi layanan terhadap tingkat kepuasan mahasiswa dalam menggunakan google classroom. Hubungan yang signifikan hanya ditunjukkan pada hubungan antara usability dan tingkat kepuasan mahasiswa dalam menggunakan Google Classroom. Besar pengaruh dari variabel kualitas antar muka pengguna terhadap tingkat kepuasan sangat kecil yaitu 0,149 (Tabel 8). Besar pengaruh dari variabel kualitas informasi terhadap tingkat kepuasan hampir tidak ada yaitu 0,011 (Tabel 8). Begitu pula dengan kualitas interaksi layanan memiliki pengaruh negatif yang sangat kecil sebesar -0,155 (Tabel 8). Sedangkan besar pengaruh dari variabel usability terhadap tingkat kepuasan mahasiswa dalam menggunakan google classroom cukup besar yaitu 0,707 (Tabel 8).

Tabel 7. Signifikansi Hubungan pada Model Struktural

\begin{tabular}{lccccc}
\hline & $\begin{array}{l}\text { Origina } \\
\text { l } \\
\text { Sample } \\
(\mathbf{O})\end{array}$ & $\begin{array}{l}\text { Sample } \\
\text { Mean (M) }\end{array}$ & $\begin{array}{l}\text { Standard } \\
\text { Deviation } \\
(\text { STDEV) }\end{array}$ & $\begin{array}{l}\text { T Statistics } \\
(\mid \text { O/STDEV })\end{array}$ & P Values \\
\hline $\begin{array}{l}\text { Kualitas Antar Muka } \\
\text { Pengguna -> Tingkat } \\
\text { Kepuasan }\end{array}$ & 0,149 & 0,162 & 0,098 & 1,525 & 0,128 \\
\hline $\begin{array}{l}\text { Kualitas Informasi -> } \\
\text { Tingkat Kepuasan }\end{array}$ & 0,011 & 0,013 & 0,117 & 0,094 & 0,925 \\
\hline $\begin{array}{l}\text { Kualitas Interaksi } \\
\text { Layanan-> Tingkat } \\
\text { Kepuasan }\end{array}$ & $-0,155$ & $-0,151$ & 0,114 & 1,362 & 0,174 \\
\hline $\begin{array}{l}\text { Usability -> Tingkat } \\
\text { Kepuasan }\end{array}$ & 0,707 & 0,697 & 0,110 & 6,413 & 0,000 \\
\hline
\end{tabular}

Tabel 8. Total Effects

\begin{tabular}{lc}
\hline \multicolumn{1}{c}{ Variabel Laten Eksogen } & $\begin{array}{c}\text { Tingkat } \\
\text { Kepuasan }\end{array}$ \\
\hline Kualitas Antar Muka Pengguna & 0,149 \\
Kualitas Informasi & 0,011 \\
Kualitas Interaksi Layanan & $-0,155$ \\
Usability & 0,707 \\
\hline
\end{tabular}

Model penyesuaian yang diperoleh memiliki nilai koefisien determinasi sebasar 0,521 (Tabel 9). Hal ini menunjukkan bahwa tingkat akurasi prediksi model hubungan antara kualitas informasi, kualitas antar muka pengguna, kualita interaksi layanan dan usability terhadap tingkat kepuasan mahasiswa dalam menggunakan google classroom adalah moderat. 
Reny Rian Marliana

Tabel 9. Koefisien Determinasi

\begin{tabular}{lcr}
\hline Variabel Endogen & R-Square & $\begin{array}{c}\text { R-Square } \\
\text { Adjusted }\end{array}$ \\
\hline Tingkat Kepuasan & 0,521 & 0,498 \\
\hline
\end{tabular}

\section{KESIMPULAN}

Berdasarkan hasil analisis yang telah dilakukan, dapat disimpulkan bahwa :

a. Kualitas Antar Muka Pengguna tidak berpengaruh secara signifikan terhadap tingkat kepuasan mahasiswa dalam menggunakan Google Classroom, dengan besar pengaruh 0,149.

b. Kualitas Informasi tidak berpengaruh secara signifikan terhadap tingkat kepuasan mahasiswa dalam menggunakan Google Classroom, dengan besar pengaruh 0,011.

c. Kualitas Interaksi Layanan tidak berpengaruh secara signifikan terhadap tingkat kepuasan mahasiswa dalam menggunakan Google Classroom, dengan besar pengaruh $-0,155$.

d. Usability berpengaruh secara signifikan terhadap tingkat kepuasan mahasiswa dalam menggunakan google Classroom, secara positif dan signfikan, dengan besar pengaruh 0,707 .

\section{DAFTAR PUSTAKA}

[1] Arifin, S. R., Nugroho, E. and Hantono, B. S., 2013. 'Analisis Kualitas Layanan Website Universitas Hasanuddin dengan Metode Webqual 4.0 Modifikasi', Teknomatika, 8(1), pp. 81-92.

[2] Asnawi, N., 2018. 'Pengukuran Usability Aplikasi Google Classroom Sebagai E-learning Menggunakan USE Questionnaire (Studi Kasus: Prodi Sistem Informasi UNIPMA)', Research: Journal of Computer, Information System \& Technology Management, 1(2), pp. 17-21.

[3] Fauziah, D. N. and Wulandari, D. A. N., 2018. 'Pengukuran Kualitas Layanan Bukalapak.com terhadap Kepuasan Konsumen dengan Metode WebQual 4.0', Jurnal Ilmu Pengetahuan dan Teknologi Komputer, 3(2), pp. 173-180.

[4] Giyanti, I. and Suparti, E., 2018. 'Penilaian Kualitas Aplikasi Halal MUI dengan WebQual 4.0 dan Pengaruhnya terhadap Keputusan Penggunaan', Jurnal Teknik Industri, 13(2), pp. 91-98.

[5] Gye-soo, K., 2016. 'Partial Least Squares Structural Equation Modeling (PLSSEMe): An application in Customer Satisfaction Research', International Journal of u- and e-Service, Science and Technology, 9(4), pp. 61-68.

[6] Joseph F. Hair, G. Tomas M.Hult, Christian M.Ringle, M. S., 2014. Partial Least Squares Structural Equation Modeling (PLS-SEM). Edited by Vicki Knight. United States of America: SAGE Publications, Inc.

[7] Jr, J. F. H. et al., 2014. 'Partial Least Squares Structural Equation Modeling (PLS-SEM) An Emerging Tool in Business Research', European Business Review, 26(2), pp. 106-121. 
[8] Manik, A., Salamah, I. and Susanti, E., 2017. 'Pengaruh Metode WebQual 4.0 terhadap Kepuasan Pengguna Website Politeknik Negeri Sriwijaya', Jurnal Elektro Telekomunikasi Terapan, Juli, pp. 477-484.

[9] Pradana, D. B. P. and Harimurti, R., 2017. 'Pengaruh Penerapan Tools Google Classroom pada Model Pembelajaran Project Based Learning Terhadap Hasil Belajar Siswa Diemas Bagas Panca Pradana Pendidikan Teknologi Informasi, Fakultas Teknik, Universitas Negeri Surabaya, IT-Edu, 02(01), pp. 59-67.

[10] Sastika, W., 2016. 'Analisis Pengaruh Kualitas Website (WEBQUAL 4. 0) terhadap Keputusan Pembelian Pada Website E-Commerce Traveloka (Studi Kasus: Pengguna Traveloka di Kota Bandung Tahun 2015)', Seminar Nasional Teknologi Informasi dan Komunikasi. Yogyakarta, Maret 18-19, pp. 649-657.

[11] Syaifullah and Soemantri, D. O., 2016. 'Pengukuran Kualitas Website Menggunakan Metode Webqual 4.0', Jurnal Rekayan dan Manajemen Sistem Informasi, 2(1), pp. 19-25.

[12] Warjiyono and Hellyana, C. M., 2018. 'Pengukuran Kualitas Website Pemerintah Desa Jagalempeni Menggunakan Metode Webqual 4.0', Jurnal Teknologi Informasi dan Ilmu Komputer (JTIIK), 5(2), pp. 139-146.

[13] Wong, K. K., 2013. 'Partial Least Squares Structural Equation Modeling (PLSSEM) Techniques using SmartPLS', Marketing Buletin, 24, Technical Note 1, pp. 1-32. 